\title{
The Impact of Urban Configuration to the Urban Heat Island in East Surabaya
}

\author{
Rivan Aji Wahyu Dyan Syafitri ${ }^{1}$, Adjie Pamungkas ${ }^{2}$, and Eko Budi Santoso ${ }^{2}$ \\ ${ }^{1}$ Department of Architecture, Institut Teknologi Sepuluh Nopember, Surabaya \\ ${ }^{2}$ Department of Urban and Regional Planning, Institut Teknologi Sepuluh Nopember, Surabaya \\ e-mail:adjieku@gmail.com
}

\begin{abstract}
Climate change that occurs due to urbanization has implications for increased intraurban heating, or usually called urban heat island (UHI). East Surabaya has the most potential to experience increased surface temperature. The urban area has different configuration characteristics and became the most fundamental impact of the phenomenon. However, East Surabaya in climate resilience response has not emphasized adaptation based on urban configuration spatially. While changing the shape of the urban that has been built is most difficult to restore and requires expensive costs. The purpose of this study is to find what's characteristics urban configuration caused UHI significantly. So, it can be a reference to an adaptation to minimize UHI intensity from the best type of urban configuration. This study uses a positivist paradigm. Remote sensing using LiDAR and Landsat imagery became the main source of this research. With geographic information system (GIS), UHI in the urban and suburban areas of East Surabaya has a temperature difference of around $1,59^{\circ} \mathrm{C}$. Characteristics of urban configuration are in classifications 2 to 7. Classification 2 is the central area of activity, while classification 7 is a sub-urban area. Urban Configuration have an impact to the UHI intensity. Classification 3 has the biggest effect on UHI.
\end{abstract}

Keywords - Remote Sensing, Urban Configuration, Urban Heat Island.

\section{INTRODUCTION}

$\mathrm{T}$ HE UHI phenomenon has been an important issue of climate change since the beginning of 1833 related to the study of the impact of local climate on temperature [1]. Urban Heat Island (UHI) is the result of urban forms and urban functions, climate, and urban geography [2]. Judging from the relationship, the urban form has a greater impact than the urban function on UHI [3]. This problem becomes important because it is almost impossible to significantly change the physical condition of the city because the built environment is largely irreversible and its modification requires large costs [4]. In the urban form, it cannot be separated from the existence of urban configuration as one of the driving factors of UHI [5]. As a result, the topic of urban configuration and UHI relations has attracted the attention of the world of urban planning, urban ecology, and climate change studies [6]. High temperatures in an urban area will create thermal discomfort [7].

UHI conditions in the city of Surabaya have a temperature difference of $\pm 1.4^{\circ} \mathrm{C}$ with a growth trend towards East Surabaya [8]. East Surabaya experienced an increase in temperature in $2001-2016$ by $6.62^{\circ} \mathrm{C}$ [9]. The tendency of temperature growth occurs on the East side which is a function area of RTH and ponds to become a residential area

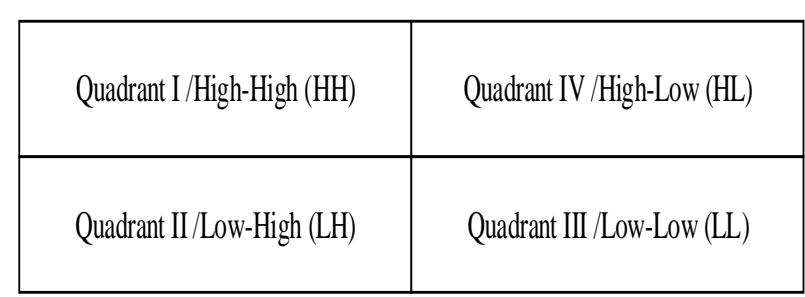

Figure 1. Distribution of scatterplot moran in spatial autocorrelation.

and the south side is a SIER industrial area [10]. The reduced green space due to massive urban development has the most fundamental impact on the urban thermal environment [11]. Judging from the urban configuration, the development of East Surabaya is also accompanied by developments in urban geometry. Large-scale buildings and high density in commercial areas tend to limit the free space of air/sky view factors that cause temperatures to tend to be trapped [9]. The relationship between changes in the area of built land cover with the average temperature of Surabaya City reached a correlation value of 0.97 and changes in vegetation land cover had a correlation value of -0.75 [12]. In order to answer the concept of New Urban Agenda number 79 in case climate change adaptation, especially the UHI phenomenon. Then it is necessary to conduct a spatial study of the effects of urban configuration characteristics on UHI. Spatial approaches at the administrative level are very effective in adapting to climate change and urban warming [13].

\section{METHODOLGY}

Figure 1 is a research methodology process.

\section{A. Spatial Distribution UHI}

\section{1) Calculate UHI value}

Identifying UHI values obtained from the 2019 surface temperature calculations. Surface temperatures obtained from Landsat 8 OIL TIRS imagery. Processing begins with radiometric corrections. Continued calculation of the value of radiance, reflectance value (ToA), the value of brightness temperature (BT), land surface emissivity (e), and land surface temperature (LST) value by referring to the formula from the Landsat handbook [14]. The surface temperature approach is used based on the formula of the normalized difference vegetation index (NDVI) [15].

Referring to the definition of UHI as a deviation between the temperature in urban and rural areas, an estimated value of the deviation occurs. UHI is a geographical phenomenon, which means that the phenomenon is influenced by the surrounding environment. In other words, the surface 
The $6^{\text {th }}$ International Seminar on Science and Technology (ISST) 2020

July $25^{\text {th }} 2020$, Institut Teknologi Sepuluh Nopember, Surabaya, Indonesia

Table 1.

Tipologi Urban Configuration

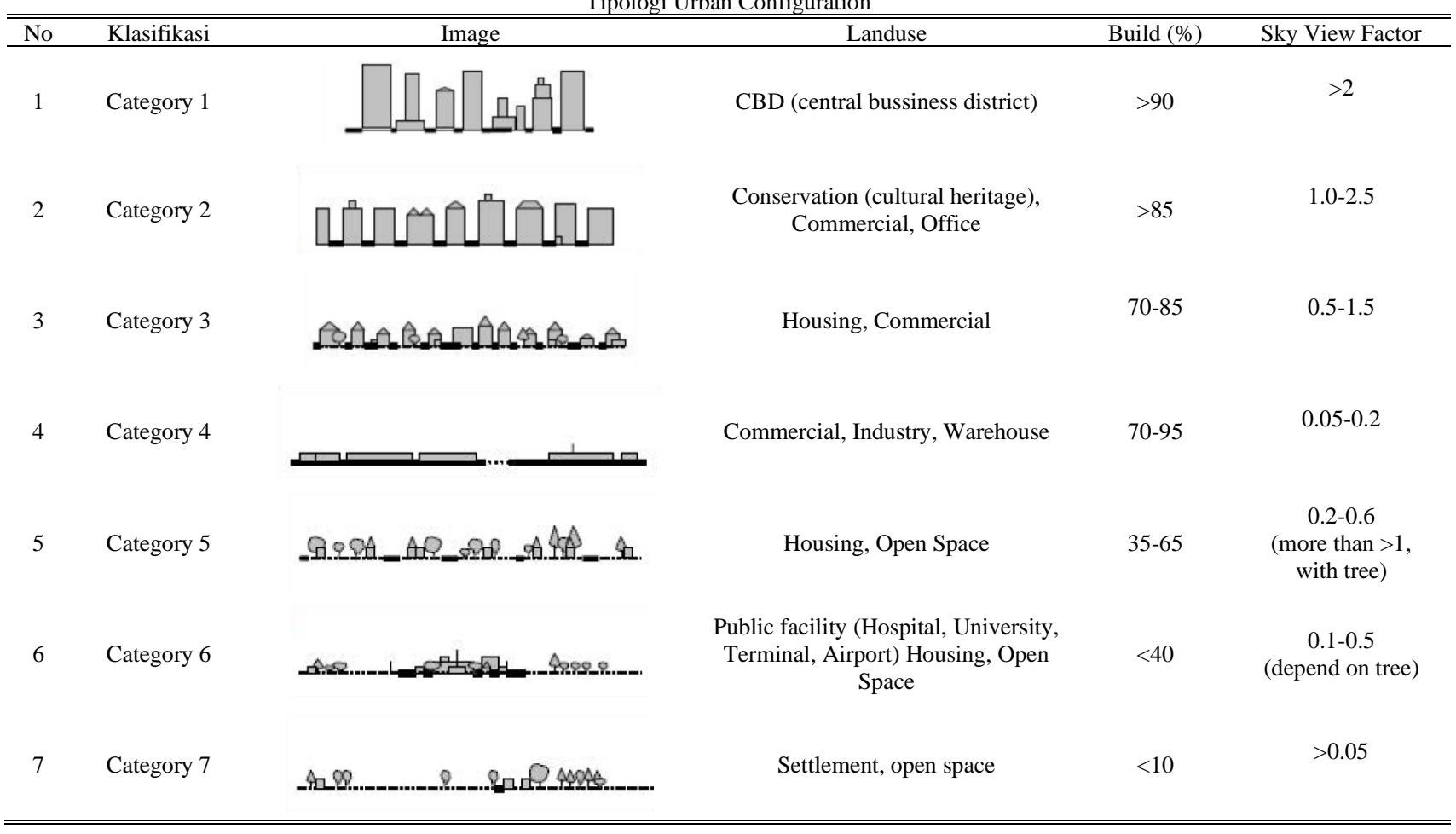

temperature pixel value represents the pixel value it self to the surrounding temperature, this is called neighborhood or neighborhood analysis [16]. Pixel neighbor analysis one of which can use the filter operation used is a $3 \mathrm{X} 3$ neighborhood filter (NF). Spatially it can be calculated using the following equation.

$$
\begin{aligned}
& \Delta \mathrm{T}_{\mu-\mathrm{r}}=\mathrm{T}_{\mu(\text { urban })-} \mathrm{T}_{\mathrm{r}(\text { suburban })} \\
& T>\mu 0,5 \alpha \text { and } 0<\mathrm{T} \leq \mu 0,5 \alpha \\
& \mathrm{UHI}_{\text {maps }}=\mathrm{T}_{\text {mean- }}(\mu 0,5 \alpha)
\end{aligned}
$$

Equation (1) is the formula intensity UHI. Where $T_{\mu}$ is the urban surface temperature, $T_{r}$ is the suburban surface temperature, $\Delta \mathrm{T} \mu-\mathrm{r}$ is the effect UHI. (2) is value max and min UHI. Where $\mathrm{T}>$ is the temperature threshold for the area in which the UHI results from neighbourhood filter, $0<$ area non-UHI, $\mu$ mean Land Surface Temperature, $\alpha$ standard deviation. (3) is formula maps distribution UHI using NF $3 \mathrm{X} 3$.

\section{2) Identification Spatial Distribution UHI}

First, the UHI map was converted into a $500 \times 500 \mathrm{~m}^{2}$ grid. This was chosen because it is considered as the simplest way to do irregular data sampling into regular grids. So that it can provide a systematic means to generalize data and plan observation routes [17].

UHI distribution patterns were identified through the Spatial Autocorrelation method with GeoDa software. Spatial autocorrelation is an estimate of the correlation between observational values related to the spatial location of the same variable. Positive autocorrelation indicates similar values from nearby locations and tend to be in groups. Whereas negative spatial autocorrelation indicates that adjacent locations have different values and tends to spread. Inside the spatial autocorrelation, there is a division of Moran's scatter plot. Moran Scatterplot can be used to identify balance or spatial influence [18].

Figure 2, quadrant I /High-High (HH), shows areas that have a high observation value surrounded by areas that have a high observation value. Quadrant II /Low-High (LH) shows areas with low observations but surrounded areas with high observation values. Quadrant III /Low-Low (LL), shows areas with low observation values and surrounded areas that also have low observation values. Quadrant IV /High-Low (HL), shows areas with high observation values that are surrounded by areas with low observation values.

\section{3) Validation}

UHI validation was carried out using an inter-comparison test approach between surface temperature radiance in Landsat images, and surface temperature radiance in ASTER images. ASTER Level-1 imagery is selected because the calculation method is not much different from Landsat Image and is equally classified as a medium-scale image [19] Radiance is temperature data received by satellite, so it is not a temperature that is on the surface of the earth which generally has been intervened by the emissivity of each image. The test is done through standardized cross-validation with RMSE (Root Mean Square Error). The RMSE value can be accepted if the RMSE <1, or the lower the RMSE the higher the validity of the estimated LST resulting from processing Landsat [20].

\section{B. Variable Urban Configuration}

Table 1 is a typology of urban areas affects the intensity of its UHI through eight categories of urban configurations [21]. 
The $6^{\text {th }}$ International Seminar on Science and Technology (ISST) 2020

July $25^{\text {th }} 2020$, Institut Teknologi Sepuluh Nopember, Surabaya, Indonesia

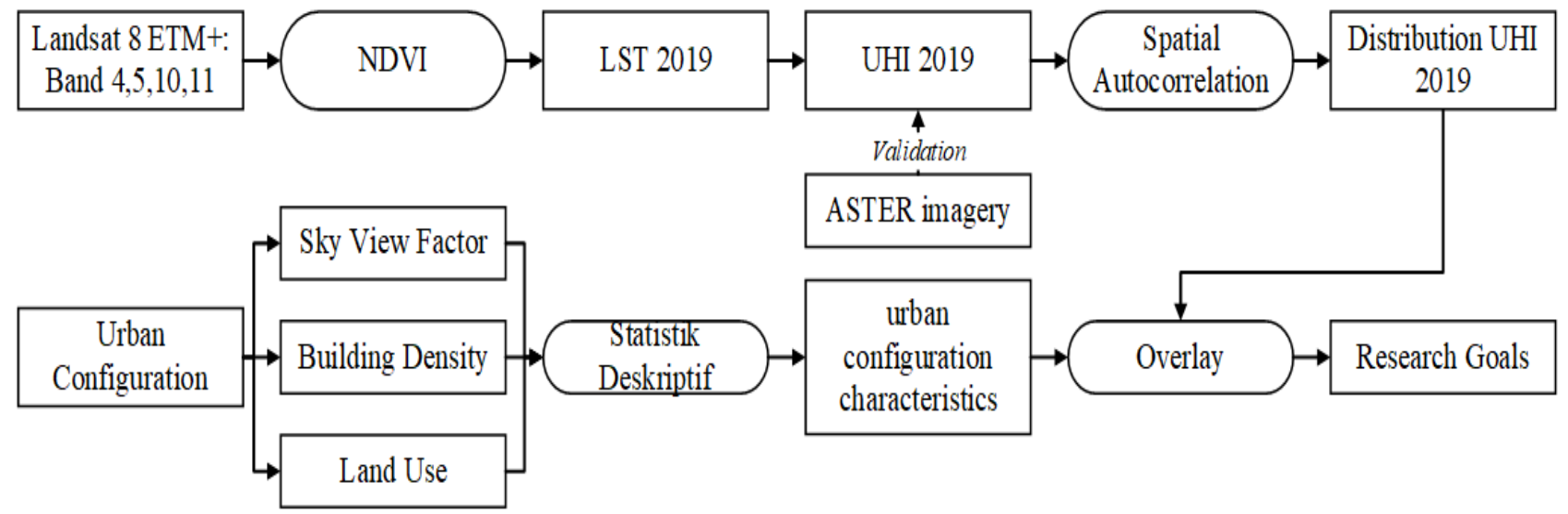

Figure 2. Research methodology process.

Table 2.

Pocess analysis classification UHI

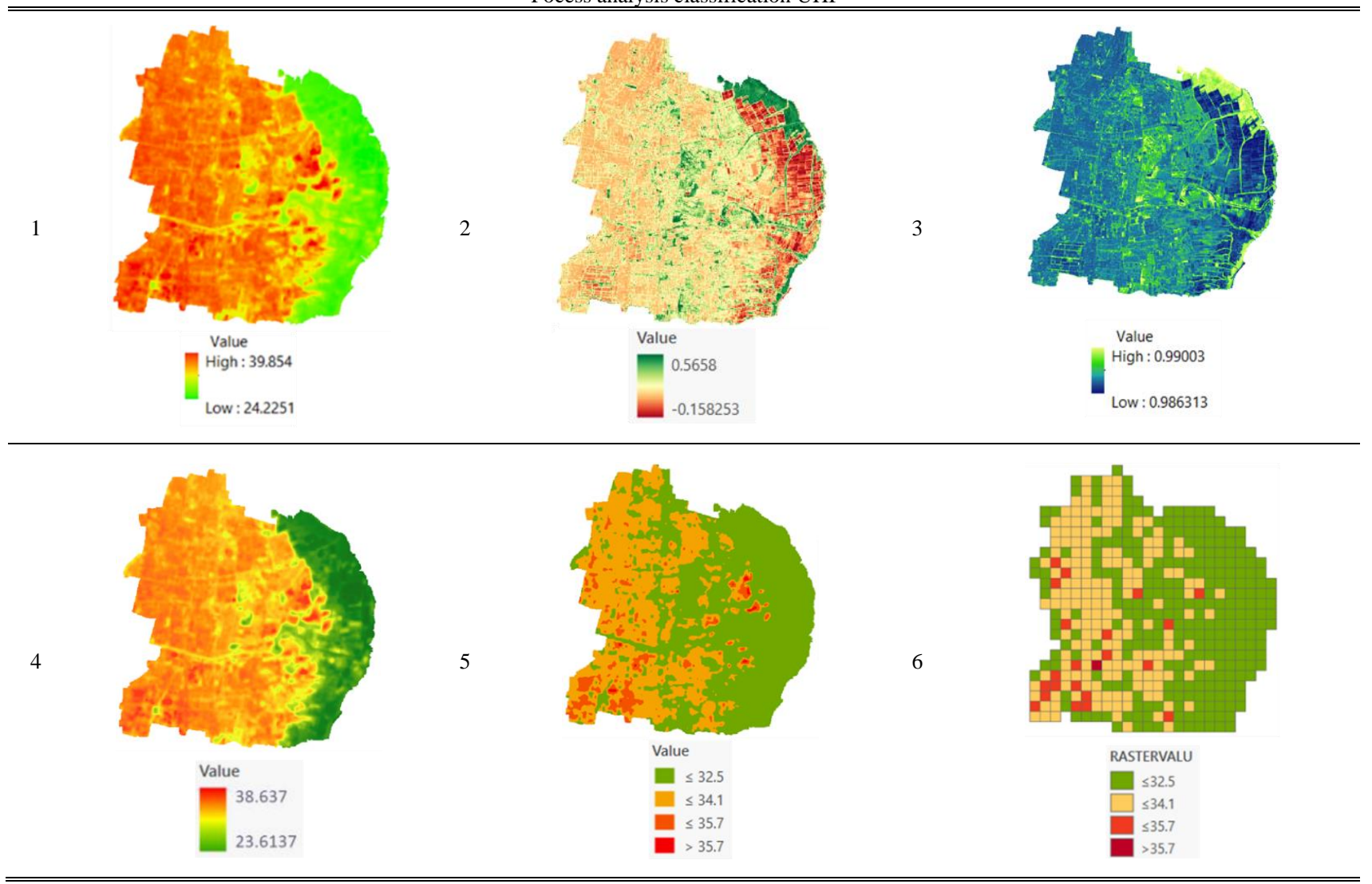

\section{1) Land use}

Land use influences the shape of the urban configuration itself. The land is built in the form of offices, and service trade is generally in the 1-4 categories. While categories 5-7 are generally areas of development of building land that is dominated by settlements. The lower the classification of urban configuration the greater the intensity of open space.

\section{2) Building density}

Building density is the percentage of land surface covered by buildings in one plot of land. Through building filtering on aerial LiDAR imagery and land use, building area data is obtained. Then it is estimated to use the raster calculator on ArcGIS.

$$
B D=\frac{\sum_{i=1}^{N} C_{i}}{C_{L}}
$$

$C_{i}$ area covered by building

$C_{L}$ is a plot of land

3) Sky view factor

Sky view factor (SVF) is the ratio between radiation received by the planar surface and the entire hemisphere radiation environment. This ratio is a $3 \mathrm{D}$ form of the $\mathrm{H} / \mathrm{W}$ ratio of the canyon/corridor to the free space of the sky. Sky view factor is obtained from the normalized value of the Digital Surface Model (nDSM), which is a reduction between the value of a digital surface model (DSM) and the value of a digital elevation model [22]. The data was obtained from LiDAR image cloud point data. SVF value estimation is done using the sky view factor calculator plugin on QGis. 
The $6^{\text {th }}$ International Seminar on Science and Technology (ISST) 2020

Table 3.

Calculation UHI

\begin{tabular}{ccccccc}
\hline \hline No & StDev & Mean & Tmax & Tmin & UHI Range & Deviation UHI \\
\hline 1 & 3,1835 & 30,9287 & 38,2387 & 23,6706 & 32,52045 & $-1,59175$ \\
\hline \hline
\end{tabular}

Figure 3. spatial autocorrelation report.
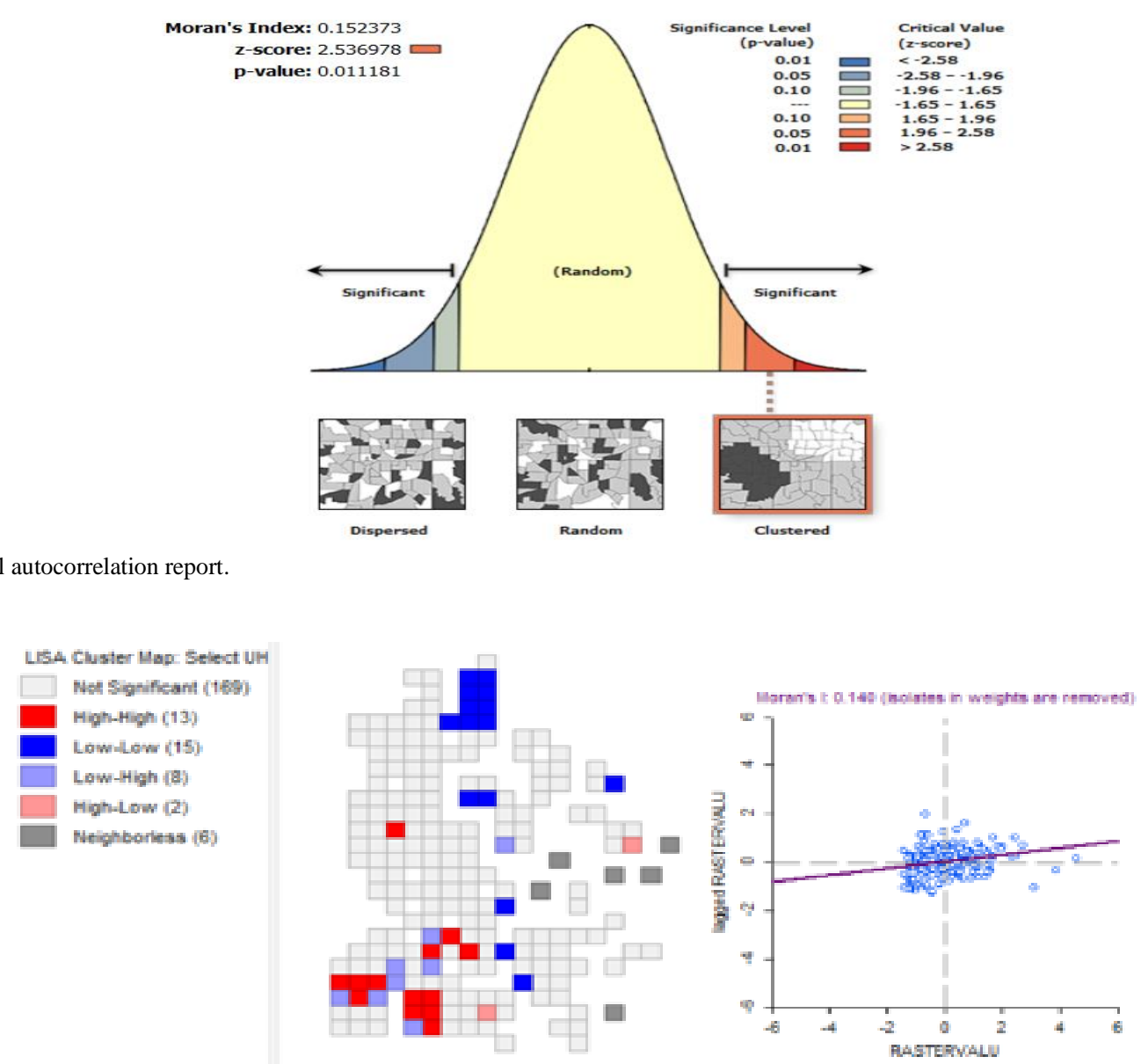

Figure 4. Spatial distribution UHI.

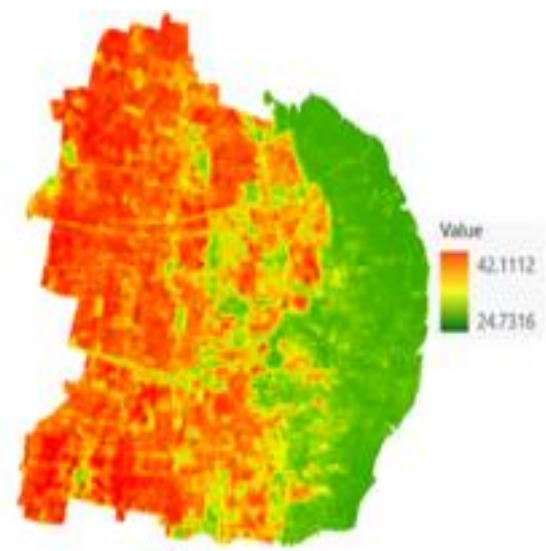

(a)

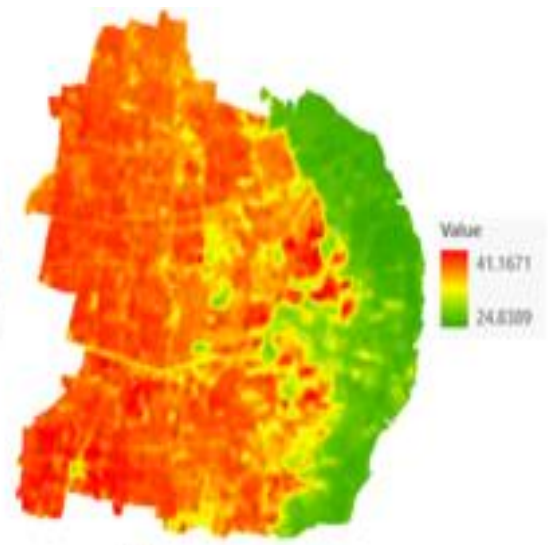

(b)

Figure 5. Radiance themperature (a) ASTER imagery, (b) Landsat imagery.

$$
\mathrm{SVF}=1-\sum_{i=1}^{N} \operatorname{Sin}^{2} \beta_{i}\left(\frac{\alpha_{i}}{360^{0}}\right)
$$

$\mathrm{N}$ : total number of angular angular elements in the hemisphere environment;

$\alpha i, \beta i \quad$ : each reflects the elevation angle and azimuth of the angle element $i$

\section{RESULT AND DISCUSSION}

A. Spatial Distribution UHI

1) Calculate UHI value

The Landsat 8 OIL TIRS imagery used was recorded on October 1, 2019, with cloud criteria $<10 \%$ and taken during 
The $6^{\text {th }}$ International Seminar on Science and Technology (ISST) 2020

July $25^{\text {th }} 2020$, Institut Teknologi Sepuluh Nopember, Surabaya, Indonesia
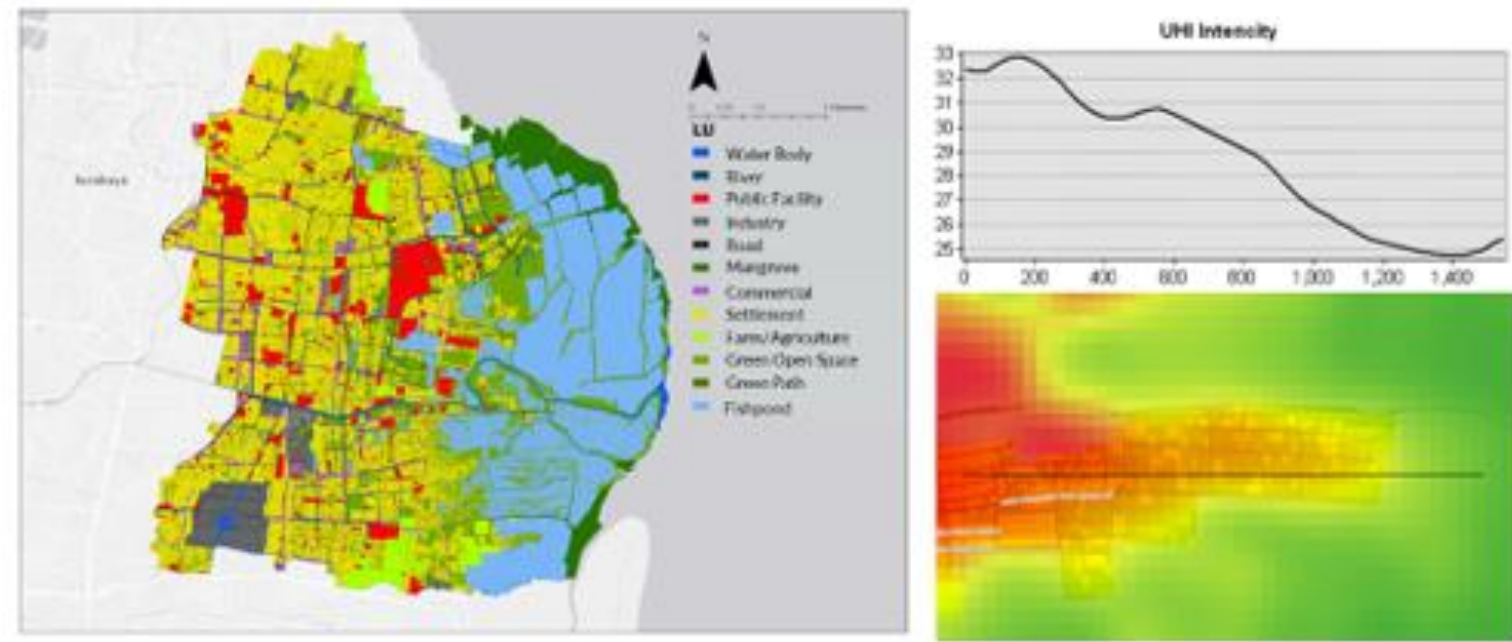

Figure 6. Land use that have impact to UHI intencity.
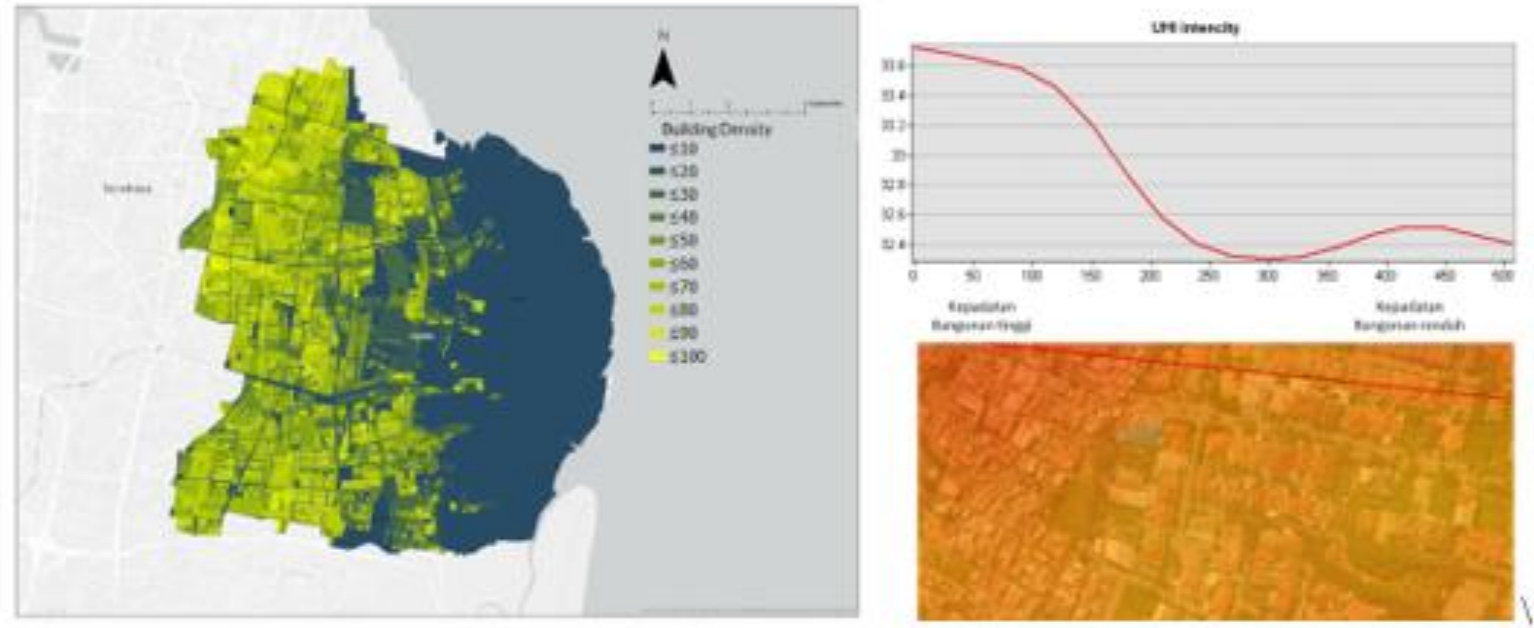

Figure 7. Building density have linear impact to UHI intencity.
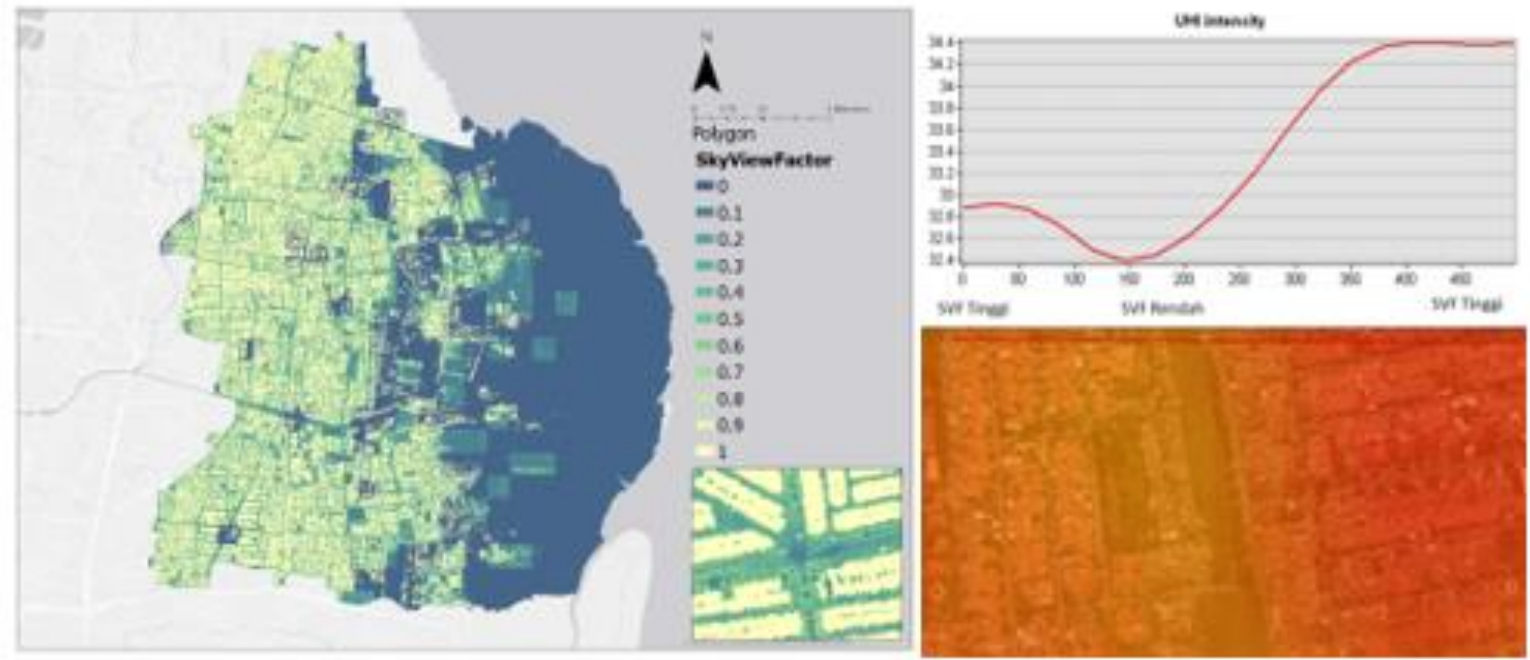

Figure 8. Sky View Factor have linear impact to UHI intencity.

the day. Next is the process of processing Landsat image bands to obtain surface temperature values. It can be observed that almost all of the land developed in the East Surabaya area is the area affected by UHI in Table 2.(5). In areas below $32.50 \mathrm{C}$ it is a non-UHI area. Industrial and commercial areas tend to have higher temperature values than other types of surfaces. From these results, Table 3 it can be observed that UHI originates from the center of Surabaya and is developing towards the sub-urban area, in this case is the Pamurbaya area. 
The $6^{\text {th }}$ International Seminar on Science and Technology (ISST) 2020

July $25^{\text {th }} 2020$, Institut Teknologi Sepuluh Nopember, Surabaya, Indonesia
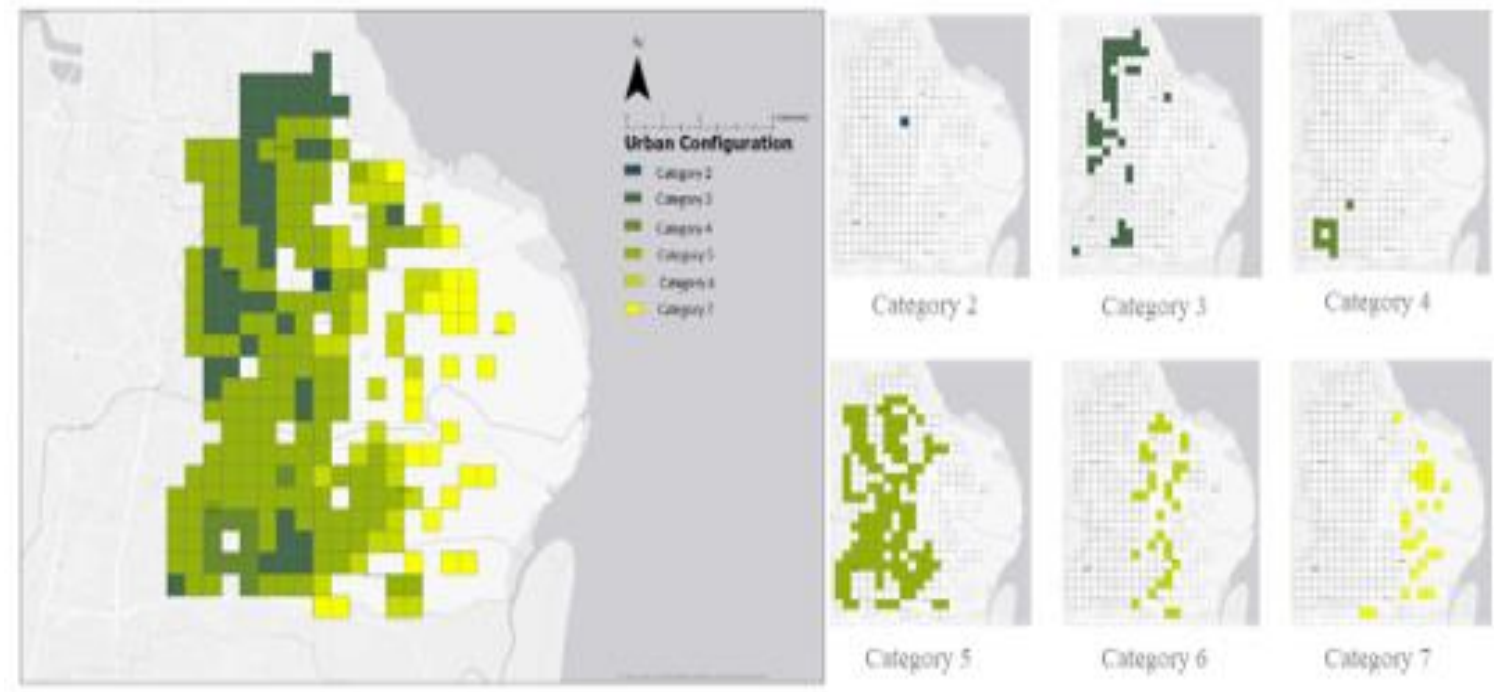

Figure 9. Classification urban configuration by grid $500 * 500$.

Table 4.

Impact urban configuration to UHI

\begin{tabular}{|c|c|c|c|c|c|c|}
\hline No & Classification & Landuse & Building Density (\%) & "Sky View Factor & UUH $\left({ }^{\circ} \mathrm{C}\right)$ & "Mean UHI $\left({ }^{0} \mathrm{C}\right)$ \\
\hline 1 & Category 2 & $\begin{array}{l}\text { Trade and services } \\
\text { (galaxy mall) and } \\
\text { settlements }\end{array}$ & 85 & $0.4-0.8$ & 31.8 & 31.8 \\
\hline 2 & Category 3 & $\begin{array}{l}\text { Settlement and trade in } \\
\text { services on road } \\
\text { corridors }\end{array}$ & $70-85$ & $0.3-0.4$ & $28-34.9$ & 33.8 \\
\hline 3 & Category 4 & Industry, warehouse & $70.2-79$ & $0.15-0.4$ & $29-36.0$ & 33.5 \\
\hline 4 & Category 5 & $\begin{array}{l}\text { Local scale trade and } \\
\text { services and public } \\
\text { facilities, low- } \\
\text { moderate density } \\
\text { settlements }\end{array}$ & $40-69$ & $0.3-0.4$ & $26.9-34.7$ & 33.3 \\
\hline 5 & Category 6 & $\begin{array}{c}\text { vacant land, shrubs / } \\
\text { swamps, low density } \\
\text { settlements, institutions }\end{array}$ & $11.9-38$ & $0.2-0.4$ & $26.5-35.6$ & 32.1 \\
\hline 6 & Category 7 & $\begin{array}{l}\text { Ponds, vacant land, } \\
\text { shrubs / swamps, } \\
\text { mangroves, low } \\
\text { density settlements }\end{array}$ & $1.8-9.8$ & $0.15-0.35$ & $26.9-35.2$ & 31 \\
\hline
\end{tabular}

\section{2) Identification Spatial Distribution UHI}

Through spatial autocorrelation analysis in Figure 3, the UHI distribution pattern has clustered characteristics. In short, high and low UHI values tend to agglomerate and form clusters. Morans index value I: 0.272728 and are in range $0>\mathrm{I}>1$ which indicates a positive autocorrelation. Hypothesis testing $\mathrm{Z}(\mathrm{I})=4.546935>\mathrm{Z}_{0.9}$ so $\mathrm{H}_{0}$ accepted, with $\mathrm{p}$-value (significance) up to 0,011 .

Next look at the Figure 4, distribution patterns with scatterplot Morran's. The result, there are 13 grids in quadrant 1 (High-High) category, 8 grids in quadrant II (Low-High), 15 grids in quadrant III (Low-Low), 2 grids in quadrant IV (High-Low), and the rest 169 grids have no influence on the surrounding area. Activities that focus on UHI-affected areas need to be given alternative adaptations to break the concentration of surface temperature by breaking down the heat center to reduce the intensity of UHI. Because the breakdown of the heat center can reduce the intensity of UHI.

\section{3) Validation}

Figure 5 shows the results of processing the ASTER image temperature radiance are in the temperature range $24-42^{\circ} \mathrm{C}$.
While the temperature radiance of Landsat images is at a temperature of $24-41^{\circ} \mathrm{C}$. It could be said to be only $0.1-1^{\circ} \mathrm{C}$.

\section{B. Identification Urban Configuration \\ 1) Variable of urban configuration \\ a) Land use}

Figure 6 shows the area affected by UHI is the area of developed land. In East Surabaya, the developed land is quite diverse, ranging from industry, trade and services, public facilities such as hospitals, educational facilities to settlements. While the non-UHI area is dominated by ponds and mangroves that are scattered along Pamurbaya (East coast of Surabaya). But now interventions over the open space function continue to occur.

b) Building density

Figure 7 shows the concept of building density is divided into blocks of built land, so that on the road there is no building density value [23]. The condition of building density in East Surabaya is quite high on the west, north and south sides. Generally dominated by settlements and industry. On the East side, the density is decreasing because it is a pond, 
The $6^{\text {th }}$ International Seminar on Science and Technology (ISST) 2020

July $25^{\text {th }} 2020$, Institut Teknologi Sepuluh Nopember, Surabaya, Indonesia

swamp and mangrove conservation area. Based on overlays with UHI, high building densities have higher intensities compared to land with lower building densities. Low building density can reduce temperatures around $0.9-1.1^{\circ} \mathrm{C}$.

c) Sky View Factor

SVF value in the study area is between $0-1$. Where for value 1 is generally on a narrow road corridor, where the surrounding buildings have a fairly high density. Whereas SVF decreases closer to 0 when it is in an open space or wide corridor. This applies also to buildings that have a wide enough border. Figure 8 shows the SVF average in East Surabaya is 0.4 . This shows that in general the urban form of the study area is a medium rise and density. In low buildings with high density will cause SVF to be high and the temperature value is also relatively high.

\section{2) Classification Urban Configuration}

Urban configuration classification criteria are based on the type of land use, sky view factor, and building density. These three variables will form 7 categories of urban configurations that represent increasing vertical and horizontal urbanization. Figure 9 shows the results of the urban configuration classification in East Surabaya.

Urban configuration results in the East Surabaya region show that the area is in the $2,3,4,5,6,7$ category. There is no category 1 because urbanization in East Surabaya does not meet "downtown" standards. The urban configuration classification is dominated by category 5 with 139 grids, which are spread almost in all areas affected by UHI. Only 1 grid is classified in category 2, namely trade and service development areas. Categories 6 and 7 are regions that have relatively fast growth compared to other categories. The construction of the MERR road and the issue of the JLLT plan (East Outer Ring Road) became a driving factor in this regard.

\section{Impact Urban Configuration to UHI}

In Table 4 of impact when comparisons are made between each category, in the case of East Surabaya, category 3 has the highest UHI characteristics compared to other categories. While category 2 as a city-scale trade and service area is not much different from categories 6 and 7. This is because the area has sufficient borders and several open areas such as rivers and fields. Thus causing the temperature circulation to be maintained properly.

\section{CONCLUSION}

In the East Surabaya region, there has been a UHI deviation of $1.590 \mathrm{C}$. UHI which occurs has a spatial distribution in a cluster. So that in areas with quadrant 1 (High-high) category based on the distribution of moran's scatterplot it is necessary to do heat breaking because in that region the temperature tends to be accumulated and has a relation to the surrounding area. It is also necessary to do a more in-depth study of this quadrant. The patterns that occur generally spread from the direction of downtown Surabaya and then develop in the suburban area. In the context of East Surabaya, industrial and residential areas tend to have hotter surface temperatures than non-built areas such as green open spaces and ponds in Pamurbaya (Pantai Timur Surabaya).
Descriptively this increase was caused by urban configuration variables such as building density, sky view factor, and land use. The urban configuration variable has an impact on UHI, although it is not linear and consistent. The point here is that the UHI value of the calculation result is not always the same as the order of the urban configuration classification. Category 2 which is the highest class in the urban configuration in East Surabaya is not the area with the highest UHI intensity. But category 3 as a high-density area dominated by settlements and trade in services. So that subsequent research recommendations need to identify other factors that cause UHI to observe inconsistent phenomena that occur. Can also do a kind of analysis of spatial relationships and regression to obtain the value of how strong the relationship between variables against UHI.

\section{REFERENCES}

[1] Howard, L., The Climate of London: Deduced from Meteorological Observations Made in the Metropolis and at Various Places around It. 1833, Harvey and Darton: London.

[2] C.Jhonson, Green Network: A Solution to the Urban Heat Island Effect, in The Sustainable City X, W.F.F.-E. C.A. Brebbia, Editor. 2015, WIT Press: WIT Transaction on Ecology and the Environtment.

[3] Ward, K.L., Steffen; Kleinschmit, Birgit; Endlicher, Wilfried, Heat waves and urban heat islands in Europe: A review of relevant drivers. J Science of the Total Environment, 2016. 569: p. 527-539.

[4] Avner, P.R., Jun; Hallegatte, Stephane, Carbon price efficiency: Lockin and path dependence in urban forms and transport infrastructure. 2014: The World Bank.

[5] Richardson, C.F.C.J.L.J.O.G., Urban heat islands: A Climate change adaptation strategy for Montreal, in The Climate Change Action Partnership. 2007, McGill University School of Urban Planning: Services des infrastructures, transport et environnement of the City of Montreal.

[6] Agathangelidis, I.C., Constantinos; Santamouris, Mat, Integrating Urban Form, Function, and Energy Fluxes in a Heat Exposure Indicator in View of Intra-Urban Heat Island Assessment and Climate Change Adaptation. J Climate, 2019. 7(6): p. 75.

[7] Venhari, A.A.T., Martin; Taleghani, Mohammad, The role of sky view factor and urban street greenery in human thermal comfort and heat stress in a desert climate. J Journal of arid environments, 2019. 166: p. 68-76.

[8] Kurniati, A.C.N., Villa; Sulistyarso, Haryo, Factors influencing urban heat island in Surabaya, Indonesia. Sustainable Cities and Society, 2016. 1.

[9] Jatayu, A.S., Cahyono, Analisis Perubahan Temperatur Permukaan Wilayah Surabaya Timur Tahun 2001-2016 Menggunakan Citra LANDSAT. J Jurnal Teknik ITS, 2018. 6(2): p. 78-82.

[10] Arifah, N.C., Susetyo Penentuan Prioritas Ruang Terbuka Hijau berdasarkan Efek Urban Heat Island di Wilayah Surabaya Timur. Jurnal Teknik ITS, 2018. Vol. 7.

[11] Kurniati, A.C.N., Villa; Sulistyarso, Haryo, Faktor-Faktor Yang Mempengaruhi Urban Heat Island Di Surabaya, Indonesia, in SEMINAR NASIONAL TEKNOLOGI. 2015: Institut Teknologi Nasional Malang.

[12] Dionysius S, B., Bangun Mulyo Sukotjo., Udiana Wahyu D., Analisa Relasi Perubahan Tutupan Lahan dan Suhu Permukaan Tanah Di Kota Surabaya Menggunakan Citra Satelit Multispektral Tahun 1994-2012. Jurnal Teknik Geomatika, 2013. Pomits Vol. 2.

[13] Rushayati, S.B.P., Lilik Budi; Puspaningsih, Nining; Rachmawati, Eva, Adaptation strategy toward urban heat island at tropical urban area. J Procedia Environmental Sciences, 2016. 33: p. 221-229.

[14] Nasa. Landsat 8 2020; Available from https://landsat.gsfc.nasa.gov/landsat-8/.

[15] Macarof, P. and S. Florian, Comparasion of NDBI and NDVI as Indicators of Surface Urban Heat Island Effect in Landsat 8 Imagery: A Case Study of Iasi. Present Environment and Sustainable Development, 2017. 11.

[16] Fawzi, N.I.J.M.I.G., Mengukur Urban Heat Island Menggunakan Penginderaan Jauh, Kasus Di Kota Yogyakarta. 2017. 19(2): p. 195206. 
The $6^{\text {th }}$ International Seminar on Science and Technology (ISST) 2020

July $25^{\text {th }} 2020$, Institut Teknologi Sepuluh Nopember, Surabaya, Indonesia

[17] Alexander, P.J. and G.J.A. Mills, Local climate classification and Dublin's urban heat island. 2014. 5(4): p. 755-774.

[18] Jatayu, A., Analisis Autokorelasi spasial pada tingkat kriminalitas provinsi jawa timur menggunkan indeks morans. 2018, Institut Pertanian Bogor: www.scribd.com.

[19] Tempfli, K., et al., Principles of remote sensing : an introductory textbook. 2009, Enschede: International Institute for Geo-Information Science and Earth Observation.

[20] Ahmadian, A.S., Chapter 8 - Design Model Development and Analysis, in Numerical Models for Submerged Breakwaters, A. Sharif
Ahmadian, Editor. 2016, Butterworth-Heinemann: Boston. p. 127-143.

[21] Oke, P.R., Initial guidance to obtain representative meteorological observations at urban sites. 2006.

[22] Aktas, Y.D.S., Jenny; Carruthers, David; Hunt, Julian, A sensitivity study relating to neighbourhood-scale fast local urban climate modelling within the built environment. J Procedia engineering, 2017. 198: p. 589-599.

[23] Cai, Z.H., Guifeng; Chen, Mingchun, Do water bodies play an important role in the relationship between urban form and land surface temperature? J Sustainable cities society, 2018. 39: p. 487-498. 